\title{
Income Diversification and Financial Performance of Selected Deposit Money Banks in Nigeria
}

\author{
Emmanuel Uniamikogbo, Rhema University, Nigeria \\ Emma I. Okoye, Nnamdi Azikiwe University, Nigeria \\ Arowoshegbe O. Amos, Ambrose Alli University, Nigeria
}

\begin{abstract}
This study examined the effect of income diversification on financial performance of deposit money banks (DMBs) in Nigeria. Variables considered were commission, foreign exchange incomes, and firm age, which are proxies for income diversification and financial performance proxied by Tobin's $\mathrm{Q}$ ratio. The purposive sampling technique was used to select the 8 banks classified by Central Bank of Nigeria to be Domestic Systematically Important Banks in Nigeria. Data collected from the annual reports and the Nigerian Stock Exchange website for a period 2008-2018 were used. Statistical tools used were the descriptive statistics and econometric analysis using the panel data. Findings showed that while commission income has a significant positive effect on Tobin's Q ratio of DMBs, foreign exchange income and firm age each have a significant negative effect on Tobin's Q ratio of DMBs in Nigeria. It is recommended that banks in Nigeria minimize their income from foreign exchange to maximize performance since income from these transactions tend to inhibit bank financial performance.
\end{abstract}

\section{KEYWORDS}

Banks, Commission, Financial Performance, Income Diversification, Tobin’s Q Ratio

\section{INTRODUCTION}

Commercial banking has remained an essential business which has contributed to the growth of economic activities around the world. The banking sector forms one of the pillars of economic development in the world through the mopping up of funds and other resources from the surplus segment of the economy and making them available to the deficit segment in return for interest income, thus, stimulating and promoting investments, economic growth and ensuring even developmental spread (Nzotta \& Okereke, 2009). Interest income from banks' intermediation activities remains banks' core income source and has been a major contributor to banks' earnings from traditional financial services prior to digital banking. A country like Nigeria with an emerging economy and 
banking sector has witnessed a tremendous growth in size, technology and competition as a result of the reforms in the Nigerian banking sector.

The banking sector across the globe plays a major role in the business of financial intermediation and has grown over the years, resulting in the diversity and complexity of its operations. Following this development, deposit money banks (DMBs) have advanced from what used to be their core line of business, which is, mobilizing deposits and advancing loans, to other financial noninterest earning intermediation services such as derivative arrangements, provision of financial guarantees, investments, foreign exchange transactions, among others. The growth of non-intermediation income activities suggests intermediation activities are becoming less important part of banking business strategies and strategically, banks have shifted their sales mix by diversifying into other income sources. These activities which are widespread in developed countries have been widely debated and reported in the academic literature (Feldman \& Schmidt 1999). The adoption of universal banking principle has made DMBs to compete on a wider range of market segments such as investment banking and market trading (Lepetit, Nys, Rous, \& Tarazi, 2008). According to Goddard (2004), banks are now able to participate in what were previously regarded as inaccessible domestic and foreign markets. This financial noninterest earning intermediation services have necessitated DMBs to naturally increase diversification by moving into fee-based activities whilst banks with already strong fee-based revenues expanded into trading activities (Elsas, Hackethal, \& Holzhäuser, 2010). DMBs generate increased portion of their income from non-intermediation activities (DeYoung $\&$ Rice, 2004) and this could be linked to financial liberalization policies.

According to Stiroh (2004), most European banks have widened their product offerings to become universal banks in the 1990s. Stiroh (2006) positively affirmed that wider revenue stream diversifies the banking industry, thus, increasing financial performance and promoting economic stability. Nevertheless, majority of those in the banking business had continued to underestimate, relegate, or misunderstood how increased noninterest income has affected the financial performance of banking companies (DeYoung \& Rice (2004). The Nigerian banking sector being an evolving one is not exempted from the evolution in the banking sector, thus the need to consider developments as it pertain to noninterest income activity in an emerging banking sector in Nigeria, relative to the realities in developed world. According to DeYoung and Rice (2004), the increasing presence of noninterest income at commercial banks has been widely documented and discussed in the industry press and regulatory publications but only a few academic studies have investigated the effect of banks' diversification (increased noninterest income) on the financial performance of DMBs in Nigeria.

The Nigerian financial sector and the banking industry have undergone series of reforms that brought changes not only in the number of banks and financial institutions but also in the diversity of products and services they render. According to DeYoung and Rice (2004), banks are increasingly exploiting nontraditional avenues of generating income, to the extent that in recent times, almost half of banks' incomes in the US are obtained from nontraditional activities and this reflects not only a diversification of banks into nontraditional activities, but also a shift in the way banks earn money. The conventional wisdom in the banking industry is that earnings from noninterest products are more stable than loan-based earnings, and that noninterest activities reduce bank risk via diversification (Nisar, Peng, Wang, \& Ashraf, 2018).

This paper is divided into five sections. Section one discusses the introduction, following the introduction is section two which focuses on literature review and hypotheses development with emphasis on: conceptual review, theoretical review and review of empirical studies. Section three harps on the methodology. This is followed by section four which focuses on the estimation results and discussion of findings, and finally, section five presents the conclusion and recommendations. 


\section{LITERATURE REVIEW AND HYPOTHESES DEVELOPMENT}

\subsection{Concept of Diversification}

The modern understanding of diversification dates back to the work of Harry Markowitz in the 1950s. Diversification is a corporate strategy to enter into a new market or industry in which the business does not currently operate, while also creating a new product for that new market. It is a risk management strategy that mixes a wide variety of investments within a portfolio. In finance, diversification is the process of allocating capital in a way that reduces the exposure to any one particular asset or risk. It is a technique that reduces risk by allocating investments among various financial instruments, industries, and other categories. The rationale behind this technique is that a portfolio consisting of different kinds of assets will on the average, yield higher long-term returns and lower the risk of any individual holdings or security. A common path towards diversification is to reduce risk or volatility by investing in a variety of assets.

The banking industry is the backbone of any economy and a diverse, profitable and stable banking system is the pre-requisite for strong and prosperous economies (Nisar, et al. 2018). However, despite the paramount importance of the banking industry in Nigeria, banking concentration and the level of domestic credit is very low owing to increase in non-performing loans whose resultant effect is unprecedentedly increasing defaults in repayment of loans, poor banking practices, non-compliance to banking regulations, unstable economic and political conditions. Hence, the need for deposit money banks to reposition their operational strategy into alternative revenue source and shift their revenue mix by diversifying into related line of businesses other than intermediating funds between the surplus and deficit units.

Theoretically and empirically, the impact of diversification on bank performance and stability has been debated on by scholars across the globe and is still debatable. According to portfolio theory, diversified banks benefit from economies of scope which improve performance and reduce risk (Elsas, Hackethal, \& Holzhäuser, 2010). Incomes from different sources which are uncorrelated or imperfectly correlated with each other result in steady and stable streams of overall bank profits (Chiorazzo, Milani, \& Salvini, 2008). On the contrary, if the diversified activity is inherently riskier than the traditional banking business, the costs of diversification may outweigh the benefits, and banks may become riskier and their overall performance may deteriorate (Boyd, Stanley, \& Hewitt, 1993). This effect would further magnify if incomes from different activities are highly correlated.

In line with the above arguments, existing empirical studies reported mixed evidence on the impact of income diversification on banks' performance. Studies (such as Berger, Iftekhar, \& Mingming, 2010 and Maudos, 2017) reported a negative impact of diversification on bank performance. On the other hand, Elsas et al., (2010) and Sanya \& Wolfe (2011) found a positive association between noninterest income diversification and performance. However, studies (such as Lee, Yang, \& Chang, 2014; Li \& Zhang, 2013) conclude that income diversification does not increase performance. Similarly, Stiroh and Rumble (2006) and De-Jonghe (2010) argue that an increase in income diversification has a negative effect on banks' stability, while Sanya and Wolfe (2011), and Lee, et al. (2014) found that income diversification increases bank performance and stability.

Given the inconclusive nature and inconsistency in their findings, this study believes additional evidence would be needed to validate whether banks' income diversification affects financial performance. Thus, this study investigates income diversification in the Nigerian banking sector, with emphasis on the effect of income diversification on financial performance of some selected DMBs in Nigeria from 2008 to 2018. This is the knowledge gap this study seeks to fill.

\subsection{Foreign Exchange Transaction Income}

Foreign exchange (FOREX) has been a major concept in international banking. Without foreign exchange, international banking would be impossible as it represents the financial part of the commercial transactions which is conducted through the payment and settlement systems of the banks 
(Osundina, Osundina, Jayeoba, \& Olayinka, 2016). Thus, foreign exchange as defined by the Business Dictionary (2015) is any currency other than the local currency which is used in settling international transactions and also a system of trading in and converting the currency of one country into that of another. According to O'Sullivan and Steven (2003), exchange rate is the value of a nation's currency in terms of another nation's currency, that is, it is the required amount of units a currency can buy for a certain amount of units of another currency. In Nigeria, it is the value of Naira in relation to other currencies such as United States Dollar, Japanese Yen, British Pounds, and so on. In the same vein, foreign exchange includes monetary authorities claims on foreigners in the form of bank deposits, treasury bills, short term and long term government securities and other claims usable in the event of a balance of payment deficit, including non-marketable claims arising from inter-central bank and inter-governmental arrangements, without regard to whether the claim is denominated in the currency of the debtor or the creditor (Babazadeh \& Farrokhnejad, 2012).

Foreign exchange transaction simply means an agreement of exchange of currencies of one country for another at an agreed exchange rate on a definite date. It is the term used to describe all operations conducted by businesses or individuals that are denominated in a currency other than a company's functional currency. Foreign exchange transaction refers to the sale and purchase of foreign currencies.

International businesses such as e-commerce multinationals or banks selling packages worldwide make hundreds or even thousands of foreign currency transactions a day, which are likely to render them vulnerable to foreign exchange risk. Firms working with more than one currency are requested to report their transactions in their financial statements in their functional currency, using the daily spot exchange rate. Sometimes, the interval between a firm's commitment being undertaken and payment being made may extend for a significant period of time. In these instances, the fluctuations of the exchange rate between the transaction currency and reporting currency can cause variations in the reported amount of the transaction, which can impact the company's profit margins. These variations are recorded in financial statements as foreign exchange gains or losses. Where such variations result in an exchange gains it is known as foreign exchange transaction income, otherwise losses.

Often, DMBs engage in foreign exchange or foreign currency transactions which are outside their normal business operations and earn income in the form of non-interest income. The non-interest income earned results from the fluctuation in the exchange rate between the transaction currency and reporting currency which brought about variations in the amount of transaction reported in the financial statements. Examples of foreign exchange transaction income include income from foreign currency and hedging transactions pertaining to foreign currency translation of receivables and payables as well as of currency derivatives and other hedging transactions, income from translation of ðnancial statements in foreign currencies which contained gains from the translation of companies whose local currency is different from the functional currency.

However, banks mitigate financial statements volatility caused by fluctuations in exchange rate using foreign exchange derivatives to hedge foreign exchange risk through the application of hedge accounting measures in the case of any envisaged foreign exchange loss. Flowing from above, the first hypothesis of this study is presumed as follows:

$\mathbf{H}_{\mathbf{0}}$ : Foreign exchange transaction income has no significant effect on Tobin's q ratio of Deposit Money Banks in Nigeria.

\subsection{Commission Income}

Commission is a service charge assessed by a broker or investment advisor in return for providing investment advice and/or handling the purchase or sale of a security. Banks are in the business of providing full-service as agents or brokers to customers, hence derive much of their profits from charging commissions on client's transactions. The income derived from commission charged on client's transactions is known as commission income. Commission income therefore, refers to income 
earned by brokers and agents in making sales or closing a deal. It is the primary revenue account of businesses that principally make earnings from making sales or closing deals for third parties. Examples of commission income include real estate brokers' commission, stock brokers' commission, insurance agencies commission, travel agencies commission, and so on.

Often, brokers and financial advisors present themselves as being fee-based rather than commission-based. The difference between a commission-based and a fee-based advisor is while a commission-based advisor derives his income from selling investment products, such as mutual funds and annuities, and conducting transactions with the client's money, a fee-based advisor charges a flat rate for managing a client's money, regardless of the type of investment products the client ends up purchasing. This flat rate is either a fixed naira amount or a fixed percentage of assets under management. On this basis, our second hypothesis is formulated as follows:

$\mathbf{H}_{\mathbf{0} 2}$ : Commission income has no significant effect on Tobin's q ratio of Deposit Money Banks
in Nigeria.

\subsection{Firm Age}

Firm age is one of the most important factors used to decompose the forces which affect survival into industries and firm attributes. On average, roughly 5-10\% of the firms in a given market leave that market over a span of a single year (Agarwal \& Gort, 2002). Kumar (2004) argues that while older firms obtain experience-based economies of scale, they are also prone to inertia and rigidities in adaptability, which could lead to lower performance. Agarwal and Gort (2002) posit that as firms get older, they start seeking outside help to function while Liargovas and Skandalis (2008) argue that mature firms possess sophisticated skills because they have enjoyed the advantages of learning and are not prone to the liabilities of newness, and therefore, they have a superior performance. The age of a firm may have an impact on firm's performance, hence the introduction (age) as a control variable in this study. We would expect a positive relationship between age and deposit money bank's financial performance in Nigeria. Thus, our third hypothesis is as follows:

\section{$\mathbf{H}_{\mathbf{0}}$ : Firm age has no significant effect on Tobin's q ratio of Deposit Money Banks in Nigeria.}

\subsection{Tobin's-Q (TQ)}

Tobin's q is one of the performance measures commonly used to measure the firm's effectiveness from an investment perspective. It defines the ratio of market value to replacement cost of tangible assets. Tobin's-q ratio is calculated as the market value of a firm divided by the replacement cost of the firm's assets. According to (Tobin, 1978; Tobin \& Brainard, 1977; Tobin, 1969; Tobin \& Brainard, 1968), Tobin's-q ratio is extensively used in the financial literature as a proxy for future investment opportunities. Tobin's-q ratio has been used in a variety of situations in the financial literature to examine different financial phenomena and decisions. The ratio has been used in research related to investment and diversification (Jose, Nichols, \& Stevens, 1986) to explain the relationship between managerial ownership and firm value. Berger and Ofek (1995) used Tobin's-q ratio to determine the firm's future financial performance. Wernerfelt and Montgomery (1988) used Tobin's-q as a measure of firm performance to estimate the relative importance of industry, focus, and share effects.

It therefore showed that a positive relationship must be observed between Tobin's-q ratio and future operating performance of a firm for the ratio to be a valid proxy for a firm's investment opportunities. Although, the ratio in its many variations is a popular choice in empirical studies, no study to our knowledge has established the linkage between Tobin's-q ratio, diversification and firm performance. The numerator of the ratio - the market value of the firm depends on discounted expected future cash flows generated by the firm's assets. Since the denominator of the ratio is simply replacement cost of assets and is expressed in present value terms, there exists an implied positive association between a 
firm's Tobin's-q ratio and its future cash flows. Prior literature has not examined this linkage between Tobin's-q ratio, diversification and firm performance.

Tobin's-q ratio is calculated thus:

Tobin's $Q=\frac{M V}{A N W}$

where:

$\mathrm{MV}=$ Market value

$\mathrm{ANW}=$ Assets net worth (that is, total assets - total liabilities)

\section{REVIEW OF THEORY}

\subsection{Modern Portfolio Theory}

The Modern Portfolio Theory (MPT) of 1952 is an investment theory developed by Markowitz. MPT is an investment framework for the selection and diversification of investment portfolios based on the maximisation of expected returns of the portfolios and the simultaneous minimisation of investment risk (Fabozzi, Gupta, \& Markowitz, 2002). This theory develops a framework where, any anticipated return has different expected outcomes, thus, guides the investor on ruling on investment portfolios. It is one of the most important and influential economic theories dealing with finance and investment management. The fundamentals of MPT are asset's risk-return on the overall investment portfolio. This theory is anchored on the belief that risk-averse investors could actually come up with investment portfolios to boost or maximize expected returns based on a given level of market risk, emphasizing that risk is an inherent part of higher reward. The MPT shows that specific risk can be removed through diversification. The two main concepts in "Modern Portfolio Theory" are that: (1). An investor's goal is to maximize return for any level of risk, and (2). Risk can be reduced by creating a diversified portfolio of unrelated assets.

The view of Markowitz (1952) is that an asset's risk and return should not be evaluated by itself, but by how it contributes to a portfolio's overall risk and return. MPT, however, shows that a mixture of diverse assets will significantly reduce the overall risk of a portfolio. That risk should be seen as a cumulative factor for the portfolio as a whole and not as a simple addition of single risk. The assumption of MPT is that investors are risk-averse, meaning that given two portfolios that offer the same expected return, investors will prefer the less risky one. Conversely, an investor who wants higher expected returns must accept more risk. The concept of "risk and return trade-off" as it relates to Markowitz's basic principle states that the riskier the investment, the greater the required potential return. Thus, generally speaking, investors will keep a risky security only if the expected return is sufficiently high enough to compensate them for assuming the risk (Ross, Westerfield, \& Jaffe, 2002). He therefore states that investors should be aware of the relationship between risk and return of a financial asset.

The risk element of MPT can be mathematically measured and reduced through diversification which aims to properly select a weighted collection of investment assets that together exhibit lower risk factors than investment in any individual asset or singular asset class. Diversification is, in fact, the core concept of MPT and directly relies on the conventional wisdom of "never putting all your eggs in one basket" (McClure, 2010; Fabozzi, et al., 2002).

The Modern Portfolio Theory (MPT) is adopted in this study as the most appropriate economic theory on finance and investment management, because literature on banks' diversification of products and services essentially from interest based activity towards noninterest based activity and its 
characteristics revolve principally around the modern portfolio theory. Also, a number of factors such as complete information available in the markets, investing in portfolio stocks rather than individuals, diversified portfolios held by investors over short observation periods and many more are the reasons for the choice of MPT model in explaining the risk-return trade-off. Moreso, the core concept of MPT is on diversification and portfolios investment. Additionally, other economic theories on finance and investment management like capital assets pricing model (CAPM) and Arbitrage Pricing Theory (APT) were upshots and iterations of MPT of Markowitz (1952).

\subsection{Review of Empirical Studies}

Ammar and Boughrara (2019) investigated the effect of revenue diversification on bank performance, shedding light on the impact of the shift towards non-interest income sources. They used a sample of 275 banks from fourteen Middle East and North Africa countries over 1990-2011. The model estimation using the Generalised Method of Moments (GMM) system reveals that diversification, when taken as a whole, improves bank profitability. They also split the non-interest income and found that trading-generating business lines contribute the most to boosting profitability and stability. They found that engaging in non-interest-related activities worsen the benefit-cost trade-off of diversification, induced by the increased insolvency risk.

Nisar, Peng, Wang, and Ashraf (2018) examined the impact of revenue diversification on the profitability and stability of South Asian commercial banks. Data for the study was collected from the annual accounting data for the commercial banks of eight South Asian countries (i.e., Afghanistan, Bangladesh, Bhutan, India, Maldives, Nepal, Pakistan and Sri-Lanka) over the period 2000-2014. Data for macroeconomic variables are taken from World Bank database and websites of central banks of individual countries and banks. They used revenue diversification as independent variable proxied by fee and commission income and other non-interest income while profitability/stability is the dependent variable proxied by ROA and ROE. Analyzing a panel dataset of 200 commercial banks from all South Asian countries, they found that overall revenue diversification into non-interest income has a positive impact on the profitability and stability of South Asian commercial banks. They further observed that different types of non-interest income-generating activities have different impacts on bank performance and stability. While fees and commission incomes have a negative impact on the profitability and stability of South Asian commercial banks, other non-interest income has a positive impact. The results imply that banks can benefit from revenue diversification if they diversify into specific types of non-interest income-generating activities. The findings are robust and relevant to the use of alternative measures of revenue diversification, profitability and stability.

Mundi (2019) investigated the impact of changing streams of bank income on bank's profitability in selected banks in India. The focus is that in today's era of competition, income streams of bank are changing. The study examined two income streams of the banks: The fund income and fee income. A database of 74 banks of public, private, and foreign banks was studied over a period of 2005 -2014 and data were collected from the CMIE Prowess. The bank performance was measured using return on equity (ROE) and a control variable, return on assets (ROA). The impact of fund income and fee income on banks profitability was analysed using multiple regressions over the period of study. The study revealed that fee income and fund income impacted moderately and positively on return on equity of banks.

Beak, Yong-Lee, Wan-Lee and Mohanty (2018) examined whether the diversification of operating income in Korean banks has persistently enhanced the performance of Korean banks. The results showed that, despite Korean banks' efforts to diversify their operating income, these banks do not gain any benefit from the diversification. Thus, bank managers in Korea focus on interest income revenue. The results also show that the increase in non-interest income revenue keeps pace with the growth in expenses, which offsets the diversification effect on the performance of Korean banks. As a result, Korean banks discourage banking diversification and focus on non-interest income revenues. 
Lambe (2018) assessed the impact of exchange rate risk on bank performance in Nigeria. The study used 2010-2016 annual reports of 15 banks listed on the Nigerian Stock Exchange and employed the secondary source of information utilizing an auto-regression conditional model as means for measuring risk. The model specified the conditional variance as a deterministic function of lagged squared residual. The study revealed that a unit increase in exchange rate is driven by an increase in profit after tax (PAT) and equally indicated that there is a significant relationship between exchange rate management and performance of financial institutions, most especially banks.

Ahamed (2017) investigated whether a shift towards noninterest income activities improves the profitability of Indian banks and, if so, how it varies across ownership groups and banks with different asset qualities using 16 banks for the period 2006- 2015. The study used multiple linear regression technique. Findings show that higher share of non-interest income yields higher profits and risk-adjusted profits; in particular when banks are involved in more trading activities. The results indicate that private foreign banks earn more risk-adjusted profits compared to public sector and private domestic banks. Furthermore, they also found that income diversification benefits more to the banks that have lower asset quality compared to the banks that have higher asset quality. The findings are insensitive to dynamic panel data estimations and alternative sample specification. The results of this study provide valuable insights for policymakers, and conclude that ensuring diversification activities enhances bank profitability, in particular for the banks that have lower asset quality.

Saunders, Schmid, and Walter (2016) examined whether diversification of banks across traditional interest generating business and non-traditional businesses enhances bank profitability and reduces risk. Based on a sample of 368,006 quarterly observations on 10,341 US banks during the period 2002-2013, and using multiple regression, they found that a higher ratio of non-interest income (derived from fees and non-core activities such as investment banking, venture capital and trading) to interest income (associated with deposit-taking and lending to retail and commercial clients) is associated with higher profitability as well as lower failure probability. Overall, the results question the benefits of "ring-fencing" bank activities.

\section{METHODOLOGY}

This study adopts the ex-post facto research design and relies on the secondary data collected from the corporate annual reports and accounts of the eight (8) sampled banks which the Central Bank of Nigeria (CBN, 2014) categorised as Domestic Systemically Important Banks (D-SIBs) in the Nigerian banking sector and whose shares were listed on the Nigerian Stock Exchange as at $31^{\text {st }}$ December, 2017. This study population is made up of 16 DMBs listed in the Nigerian Stock Exchange as at $31^{\text {st }}$ December 2017. The judgmental sampling technique was used to select the sample size from the population. The study covered a period of eleven (11) years covering 2008-2018. The statistical tools employed were the descriptive statistics and econometric analysis. Multiple regression model was employed to capture four (4) variables comprising dependent and independent variables. The specified variables are Tobin's Q, Foreign exchange transaction income, commission income, and firm size. Data generated from the selected banks' corporate annual reports and accounts were analysed using tables and regression.

The model is expressed functionally as:

Tobin's Q Ratio $=f($ Foreign exchange transaction income, Fee commission income, Firm age $)$

The econometric model is expressed thus:

$\mathrm{TQ}_{\mathrm{it}}=\beta_{0}+\beta_{1} \mathrm{FET}_{\mathrm{it}}+\beta_{2} \mathrm{COM}_{\mathrm{it}}+\beta_{3} \mathrm{FAGE}_{\mathrm{it}}+\varepsilon_{\mathrm{it}}$ 
where:

$\mathrm{TQ}=$ Tobin's q

FET $=$ Foreign exchange transaction Income

$\mathrm{COM}=$ Commission Income

FAGE $=$ Firm Age

$\mathrm{i}(=1,2,3, \ldots 8)$ is the given deposit money banks

$\mathrm{t}=$ Time dimension of the variant

$\varepsilon=$ error term

$\beta_{0}=$ the intercept coefficient

$\beta_{1-} \beta_{3}=$ the coefficients of the parameter estimate

Also, $\beta_{1}, \beta_{2}, \beta_{3}<0$

\section{RESULTS AND DISCUSSION}

This analysis involves the use of both statistical and econometric methods in order to provide a rich background for the investigation. The statistical tools employed are the descriptive statistics and correlation analysis. The descriptive statistics are used to provide the initial characterisation of the data. The econometric analysis extends the statistical analysis with the goal of performing the empirical analysis and obtaining estimated coefficients which are valid enough to test the hypotheses in the study. The Panel Data Analysis method was employed in the econometric analysis. The descriptive statistics of the data is presented in Table 1.

Table 1. Descriptive statistics of the data

\begin{tabular}{|c|c|c|c|c|c|c|c|c|}
\hline & Mean & Max. & Min. & $\begin{array}{l}\text { Std. } \\
\text { Dev. }\end{array}$ & Skew. & Kurt. & J-B & Prob. \\
\hline $\mathrm{COMSH}$ & 8.91 & 49.32 & 0.14 & 8.38 & 2.76 & 12.76 & 461.05 & 0.000 \\
\hline FETSH & 12.01 & 85.83 & -0.22 & 17.08 & 2.71 & 10.11 & 292.68 & 0.000 \\
\hline FAGE & 37.47 & 124.00 & 3.00 & 33.18 & 1.76 & 4.82 & 57.80 & 0.000 \\
\hline TQR & 0.83 & 5.22 & -0.01 & 0.80 & 2.17 & 11.49 & 332.95 & 0.000 \\
\hline
\end{tabular}

Source: Researchers' computation, 2019

Table 1 presents the mean, standard deviation and other statistics on income diversification and other variables for the sample banks in Nigeria. The descriptive statistics shows that average share of commission income in total revenues for the banks are 8.91 percent and 12.01 percent for foreign exchange transactions incomes. This shows that more of the diversified income for the banks comes from foreign exchange activities, followed by commissions. The result also shows that some banks had up to 85.83 percent of total revenues in form of foreign exchange transactions income and 49.32 percent of total revenues as commission income. This suggests that individual banks may have varied income proportions with respect to contributions of other income activities. The standard deviations for each of the variables are relatively close to their respective mean values, suggesting that the average revenues shares of each of the income categories appear to be considerably stable across banks in the sample. Apparently, the patterns of other income sourcing by the banks do not change extensively over time or across banks. It appears the leading sources of other income for the different banks are essentially similar as well as the least sources of such income among the banks. 
The J-B tests for each of the income categories are high and easily passed the significance tests at the 1 percent level indicating that the datasets are non-normally distributed. These show clear cases of heterogeneity in the data sets across the banks. Essentially, the non-normal distribution shows that there are strong bank-specific influences on the outcome of each of the indicators values.

The summary statistics in Table 1 for performance variable shows that average Tobin's $Q$ for the banks is 0.83 . This suggests that the banks' performance is relatively low and not significant in terms of the market. The Table also shows that certain banks had very low Tobin's Q ratios for certain years, while some other banks had values up to 5.52 percentage points. The average age for the banks is however high at 37.4 years, with a standard deviation value of 33.18 which suggests a very high degree of variations across the banks in the sample.

The result as analysed from the time series data extracted from the Annual Reports \& Accounts, and the Nigerian Stock Exchange websites for the selected banks from 2008 to 2018 were presented in Table 2.

Table 2. Panel EGLS regression analysis testing the effect of COM, FET, FAGE on TQR of deposit money banks in Nigeria

\begin{tabular}{|c|c|c|c|c|}
\hline \multicolumn{5}{|c|}{ Dependent Variable: TQR } \\
\hline \multicolumn{5}{|c|}{ Method: Panel EGLS (Period weights) } \\
\hline \multicolumn{5}{|c|}{ Total panel (balanced) observations: 88} \\
\hline \multicolumn{5}{|c|}{ Linear estimation after one-step weighting matrix } \\
\hline Variable & Coefficient & Std. Error & $\mathrm{t}$-Statistic & Prob. \\
\hline $\mathrm{C}$ & -7.225921 & 1.716360 & -4.210027 & 0.0001 \\
\hline LCOM & 0.433104 & 0.098914 & 4.378612 & 0.0000 \\
\hline LFET & -0.140712 & 0.052905 & -2.659689 & 0.0097 \\
\hline \multirow[t]{2}{*}{ LAGE } & -0.334234 & 0.095372 & -3.504513 & 0.0008 \\
\hline & \multicolumn{2}{|c|}{ Weighted Statistics } & & \\
\hline R-squared & 0.607789 & \multicolumn{2}{|c|}{ Mean dependent var } & 1.126361 \\
\hline Adjusted R-squared & 0.512538 & \multicolumn{2}{|c|}{ S.D. dependent var } & 1.040097 \\
\hline S.E. of regression & 0.690114 & \multicolumn{2}{|c|}{ Sum squared resid } & 33.33797 \\
\hline F-statistic & 6.380916 & \multicolumn{2}{|c|}{ Durbin-Watson stat } & 1.172288 \\
\hline \multirow[t]{2}{*}{ Prob(F-statistic) } & 0.000000 & & & \\
\hline & \multicolumn{2}{|c|}{ Unweighted Statistics } & & \\
\hline R-squared & 0.360598 & \multicolumn{2}{|c|}{ Mean dependent var } & 0.829318 \\
\hline Sum squared resid & 35.73758 & \multicolumn{2}{|c|}{ Durbin-Watson stat } & 1.100369 \\
\hline
\end{tabular}

Source: E-view 9.0 Regression Output, 2019

\subsection{Interpretation of Regression Result}

As revealed from Table 2, the effect of commission income, foreign exchange transaction and firm age on Tobin's $Q$ ratio was examined in this study. The result for commission income is positive and statistically significant with the coefficient $\left(\beta_{1}\right)$ of 0.433 ; t-value $=4.38$ and an associated probability of 0.0000 . This indicates that commission income has a positive and significant effect on Tobin's $\mathrm{Q}$ ratio of deposit money banks in Nigeria. The probability value of $0.0000<0.05$ confirms the significance of the influence. The coefficient of determination as revealed by $R$-squared $\left(R^{2}\right)$ indicates that $6 \%$ of the variations observed in the dependent variable (Tobin's $Q$ ratio) rate were explained by 
variations in the independent variables. On the whole, the overall probability (F-statistics) is 0.0000 which is less than 0.05 properly explains the significance of commission income on Tobin's Q ratio of the banks in Nigeria within the period under review.

This implies that a one percent rise in commission income brings about 0.433 percent rise in Tobin's Q ratio of deposit money banks in Nigeria. The study results have validated that commission income has a significant positive effect on the banks' Tobin's Q ratio in Nigeria. Commission income as revealed by our findings had the highest contribution to bank revenues and the biggest and most important contributor to the financial performance (Tobin's Q ratio) of the banks in this study. Thus, increased income from commission tends to boost the value of banks Tobin's Q ratio in Nigeria. Since the p-value of 0.000 is less than the critical value of $0.05(5 \%)$, thus, $\mathrm{Ho}_{2}$ is accepted which upholds that there is a significant effect of commission income on Tobin's $Q$ ratio of deposit money banks in Nigeria.

The effect of foreign exchange transaction income on Tobin's $Q$ ratio is negative and statistically significant with the coefficient $\left(\beta_{1}\right)$ of -0.141 ; t-value $=-2.66$ and an associated probability of 0.0097 . This indicates that foreign exchange transaction income has a negative and significant effect on Tobin's Q ratio of deposit money banks in Nigeria. The probability value of $0.0097<0.05$ confirms the significance of the connection.

Though, the results show that banks that perform better tend to record higher income from foreign exchange transactions, the implication is that an increase in the income structure of foreign exchange transaction leads to 0.141 percent drop in Tobin's Q ratio of banks in Nigeria. This shows that foreign exchange transaction though increases revenue but do not guarantee the expansion on the overall performance in terms of Tobin's Q of the banks in Nigeria. Since the p-value of 0.0097 is less than the critical value of $0.05(5 \%)$, thus, $\mathrm{Ho}_{2}$ is accepted which upholds that there is a significant effect of commission income on Tobin's $Q$ ratio of deposit money banks in Nigeria.

On firm age, the result revealed a significant but negative effect between firm age and Tobin's $Q$ ratio with the coefficient $\left(\beta_{1}\right)$ of 0.3342 ; $\mathrm{t}$-value $=-3.5045$ and an associated probability of 0.0008 . This indicates that firm age has a significant negative effect on Tobin's Q ratio of deposit money banks in Nigeria. The probability value of $0.0008<0.05$ confirms the significance influence on the banks Tobin's $\mathrm{Q}$ for the period under review. This implies that a one percent rise in firm age brings about 0.3342 percent fall in Tobin's Q of deposit money banks in Nigeria. This indicates that the age of banks matters in determining firm valuation, with older banks having lower valuation and performance. Since the p-value of 0.0008 is less than the critical value of $0.05(5 \%)$, thus, $\mathrm{H}_{02}$ is accepted which upholds that there is a significant effect of firm age on Tobin's Q ratio of deposit money banks in Nigeria.

To further substantiate the validity of Tobin's Q ratio following the arguments from some quarters that it is an outdated analytical model hence, does not possess the ability to accurately predict markets during bearish periods, an alternative model was formulated using Market Value Added which is an increase in the share market value of a nominal amount of equity capital that has been provided by the shareholders as basis for financial performance measurement. The market value which provides accurate information on the current market value of a firm has a predictive ability of the markets. This informed the researchers' decision in employing the market value model in analysing this study with a view to validating the findings from Tobin's $Q$ ratio used in this study.

The market value model is expressed functionally as:

Market value added $=f($ Foreign exchange transaction income, Fee commission income, Firm age $)$

The econometric model is expressed thus:

$\mathrm{MVA}_{\mathrm{it}}=\beta_{0}+\beta_{1} \mathrm{FET}_{\mathrm{it}}+\beta_{2} \mathrm{COM}_{\mathrm{it}}+\beta_{3} \mathrm{FAGE}_{\mathrm{it}}+\varepsilon_{\mathrm{it}}$ 
where:

MVA $=$ Market value added

$\mathrm{FET}=$ Foreign exchange transaction Income

$\mathrm{COM}=$ Commission Income

FAGE $=$ Firm Age

$\mathrm{i}(=1,2,3, \ldots 8)$ is the given deposit money banks

$\mathrm{t}=$ Time dimension of the variant

$\varepsilon=$ error term

$\beta_{0}=$ the intercept coefficient

$\beta_{1-} \beta_{3}=$ the coefficients of the parameter estimate

and:

$\beta_{1}, \beta_{2}, \beta_{3}<0$

The results of the model using the same explanatory variables and data were presented in Table 3 .

Table 3. Panel EGLS regression analysis testing the effect of COM, FET, FAGE on MVA of deposit money banks in Nigeria

\begin{tabular}{|c|c|c|c|c|}
\hline \multicolumn{4}{|c|}{$\begin{array}{l}\text { Dependent Variable: MVALR } \\
\text { Method: Panel EGLS (Period random effects) }\end{array}$} & \\
\hline \multicolumn{4}{|c|}{ Total panel (balanced) observations: 88} & \\
\hline \multicolumn{5}{|c|}{ Swamy and Arora estimator of component variances } \\
\hline Variable & Coefficient & Std. Error & $\mathrm{t}$-Statistic & Prob. \\
\hline $\mathrm{C}$ & 256.4957 & 52.26408 & 4.907686 & 0.0000 \\
\hline LCOM & 11.41135 & 3.506796 & 3.254068 & 0.0017 \\
\hline LFCT & -7.833590 & 2.075329 & -3.774626 & 0.0003 \\
\hline \multirow[t]{3}{*}{ LAGE } & -1.460607 & 3.983897 & -0.366628 & 0.7149 \\
\hline & \multicolumn{2}{|c|}{ Effects Specification } & & \\
\hline & & & S.D. & Rho \\
\hline \multicolumn{2}{|l|}{ Period random } & & 0.000000 & 0.0000 \\
\hline \multicolumn{3}{|l|}{ Idiosyncratic random } & 21.18971 & 1.0000 \\
\hline & \multicolumn{2}{|c|}{ Weighted Statistics } & & \\
\hline R-squared & 0.674318 & \multicolumn{2}{|l|}{ Mean dependent var } & 11.95507 \\
\hline Adjusted R-squared & 0.645821 & \multicolumn{2}{|l|}{ S.D. dependent var } & 34.65423 \\
\hline S.E. of regression & 20.62376 & \multicolumn{2}{|l|}{ Sum squared resid } & 34027.15 \\
\hline F-statistic & 23.66261 & \multicolumn{2}{|l|}{ Durbin-Watson stat } & 1.147490 \\
\hline \multirow[t]{2}{*}{ Prob(F-statistic) } & 0.000000 & & & \\
\hline & \multicolumn{2}{|c|}{ Unweighted Statistics } & & \\
\hline R-squared & 0.674318 & Mean dependent var & & 11.95507 \\
\hline Sum squared resid & 34027.15 & Durbin-Watson stat & & 1.147490 \\
\hline
\end{tabular}

Source: E-view 9.0 Regression Output, 2019 


\subsection{Interpretation of Regression Result}

As shown in Table 3, the effect of commission income, foreign exchange transaction income and firm age on MVA was equally examined using MVA as an additional performance tool to validate the earlier findings of this study. The result for commission income is positive and statistically significant with the coefficient $\left(\beta_{1}\right)$ of 11.411 ; $\mathrm{t}$-value $=3.25$ and an associated probability of 0.0017 . This indicates that commission income has a positive and significant effect on MVA of deposit money banks in Nigeria. The probability value of $0.0017<0.05$ confirms the significance of the influence.

The effect of foreign exchange transaction income on MVA as revealed in Table 3 is also negative and statistically significant with the coefficient $\left(\beta_{1}\right)$ of -7.834 ; $\mathrm{t}$-value $=-3.77$ and an associated probability of 0.0003 . This equally indicates that foreign exchange transaction income has a negative and significant effect on MVA of deposit money banks in Nigeria. The probability value of 0.0003 $<0.05$ confirms the significance of the relationship. The implication is that though income from foreign exchange transaction increases revenue however, it does not guarantee the expansion of the market value of banks in Nigeria. With the p-value of 0.0003 less than the critical value of $0.05(5 \%)$, we therefore accept $\mathrm{Ho}_{2}$ and upholds that commission income has a significant effect on MVA of deposit money banks in Nigeria.

The outcomes of the alternative analytical model presented in Table 3 using MVA is in consonance with that of Table 2 using Tobin's Q ratio for financial performance evaluation. Findings from both analyses revealed that while commission income had positive and significant influence on Tobin's $\mathrm{Q}$ and MVA respectively, foreign exchange transaction income had negative and significant effects each on Tobin's Q and MVA. This study alternative findings do not only independently validate the efficacy of Tobin's Q ratio in perfectly and accurately predicting the markets during bearish periods, but has further refuted the positions of some scholars (such as Doug Henwood and Wall Street) who in their views argued that Tobin's Q ratio lacks the ability to accurately predict the markets. This study thus, disagrees with the findings of Doug Henwood and Wall Street which opined that Tobin's $\mathrm{Q}$ ratio is outdated hence, cannot predict the markets with precision during periods of downtrend.

\section{CONCLUSION AND RECOMMENDATIONS}

\subsection{Conclusion}

This study covers the statistical analysis and interpretation of fitting regression models between income diversification and Tobin's Q ratio of deposit money banks in Nigeria. The models were to identify the extent to which other income captured with commission income (COM), foreign exchange transaction income (FCT) and firm age (FAGE) are influential in predicting the financial performance (Tobin's Q ratio) of deposit money banks in Nigeria. Tobin's $Q$ ratio was used as financial performance variable. The data extracted for the analysis covered a period of eleven (11) years starting from 2008 to 2018. The findings indicated clearly that commission income exerts a positive significant influence on Tobin's Q ratio of banks while foreign exchange transaction income and firm age exert a significant negative influence on Tobin's Q ratio of deposit money banks in Nigeria at5\% significant level.

This findings is in consonance with the works of Alubisia, Githii, and Mwangi (2018), Yang, Li, Ma, and Chen (2018), Adedeji and Adedeji (2018), Huseyin (2018), Mundi (2019), Gueyié, Guidara, and Lai (2019) who examined the effect of noninterest income (disaggregated into noninterest income fee and commission income, capital adequacy ratio, overheads foreign exchange income loans and bank size) on financial performance and found that commission income had significant positive influence on financial performance of banks while foreign exchange income had negative significant effect on financial performance of banks thus, re-echoing the need for increase and encouragement for the banking sector diversification into noninterest based activities which have proven over the years as an alternative and more efficient revenue generating source for the banks with a view to improving their financial performance and stability. This study however, negates the studies by LiLi 
(2014), Gichure (2015), Beak, Yong Lee, Wan Lee and Mohanty (2018), and Andrzejuk (2019) who examined the influence of noninterest income on financial performance of banks and found an insignificant influence between commission income, foreign exchange transaction income, firm age, and financial performance of banks.

\subsection{Recommendations}

Based on the findings, the following recommendations were suggested:

1. Banks should minimise their income from foreign exchange transactions in order to maximise their performance (Tobin's Q ratio), since higher incomes from these transactions tend to inhibit the value of banks in terms of their financial performance in Nigeria;

2. Older banks should focus on their core intermediary functions and reduce the level with which they diversify into noninterest activities since it lowers their value and financial performance;

3. Retail oriented banks are encouraged to invest more on noninterest activities in the area of commission since it contributes significantly and positively to revenue and performance (Tobin's Q) of banks in Nigeria. 


\section{REFERENCES}

Ahamed, M. M. (2017). Asset quality, non-interest income, and bank profitability: Evidence from Indian banks. Economic Modelling, 63, 1-14. doi:10.1016/j.econmod.2017.01.016

Ammar, N., \& Boughrara, A. (2019). The impact of revenue diversification on bank profitability and risk: Evidence from Middle East and North Africa banking industry. Macroeconomics and Finance in Emerging Market Economies, 12(1), 1-35. doi:10.1080/17520843.2018.1535513

Babazadeh, M., \& Farrokhnejad, F. (2012). Effects of Short-run and Long-run Changes in Foreign Exchange Rates on Banks "e Profit. International Journal of Business and Management, 7(17), 70-77. doi:10.5539/ijbm.v7n17p70

Beak, S., Yong Lee, K., Wan Lee, J., \& Mohanty, S. K. (2018). Diversification in Korean banking business: Is non-interest income a financial saviour? Journal of Emerging Market Finance, 17(2), S299-S326. doi:10.1177/0972652718798079

Berger, A. N., Iftekhar, H., \& Mingming, Z. (2010). The effects of focus versus diversification on bank performance: Evidence from Chinese banks. Journal of Banking \& Finance, 34(7), 1417-1435. doi:10.1016/j. jbankfin.2010.01.010

Berger, P., \& Ofek, E. (1995). Diversification's effect on firm value. Journal of Financial Economics, 37(1), 39-66. doi:10.1016/0304-405X(94)00798-6

Boyd, J. H., Stanley, L. G., \& Hewitt, R. S. (1993). Bank holding company mergers with nonbank financial firms: Effects on the risk of failure. Journal of Banking \& Finance, 17(1), 43-63. doi:10.1016/0378-4266(93)90079-S

Business dictionary. (2015). http://www.businessdictionary.com/definition/foreign exchange-Forex-or-FX.html

Central Bank of Nigeria. (2014). Framework for the regulation and supervision of domestic systemically important banks (SIBs) in Nigeria. Author.

Chiorazzo, V., Milani, C., \& Salvini, F. (2008). Income diversification and bank performance: Evidence from Italian banks. Journal of Financial Services Research, 33(3), 181-203. doi:10.1007/s10693-008-0029-4

De Jonghe, O. (2010). Back to the basics in banking? A micro-analysis of banking system stability. Journal of Financial Intermediation, 19(3), 387-417. doi:10.1016/j.jfi.2009.04.001

DeYoung, R., \& Rice, T. (2004). Non-interest income and financial performance at U.S. commercial banks. Financial Review, 39(1), 456-478. doi:10.1111/j.0732-8516.2004.00069.x

Elsas, R., Hackethal, A., \& Holzhäuser, M. (2010). The anatomy of bank diversification. Journal of Banking \& Finance, 34(6), 1274-1287. doi:10.1016/j.jbankfin.2009.11.024

Fabozzi, F., Gupta, F., \& Markowitz, H. (2002). The legacy of modern portfolio theory. Journal of Investing, 11(3), 7-22. doi:10.3905/joi.2002.319510

Feldman, R., \& Schmidt, J. (1999). Non-interest income: A potential for profits, risk reduction, and some exaggerated claims. Federal Reserve Bank of Minneapolis, Fedgazette.

Hummelberg, C. P., Hubband, R. G., \& Palia, D. (1999). Understanding the determinants of managerial ownership and the link between ownership and preference. Journal of Financial Economics, 53(3), 353-384. doi:10.1016/ S0304-405X(99)00025-2

Jose, M. L., Nichols, L. M., \& Stevens, J. L. (1986). Contributions of diversification, promotion, and research \&development to the value of multiproduct firms: A Tobin's q Approach. Financial Management, 15(4), 33-42. doi: $10.2307 / 3665778$

Lambe, I. (2018). Assessing the impact of exchange rate risk on banks performance in Nigeria. Journal of Economics and Sustainable Development, 6(6), 1-13.

Lee, C. C., Yang, S. J., \& Chang, C. H. (2014). Non-interest income, profitability, and risk in banking industry: A cross-country analysis. The North American Journal of Economics and Finance, 27, 48-67. doi:10.1016/j. najef.2013.11.002 
Lepetit, L., Nys, E., Rous, P., \& Tarazi, A. (2008). The expansion of services in European banking: Implications for loan pricing and interest margins. Journal of Banking \& Finance, 32(11), 2325-2335. doi:10.1016/j. jbankfin.2007.09.025

Li, L., \& Zhang, Y. (2013). Are there diversification benefits of increasing noninterest income in the Chinese banking industry? Journal of Empirical Finance, 24, 151-165. doi:10.1016/j.jempfin.2013.10.004

Markowitz, H. (1952). Portfolio Selection. The Journal of Finance, 7(1), 77-91.

Maudos, J. (2017). Income structure, profitability and risk in the European banking sector: The impact of the crisis. Research in International Business and Finance, 39, 85-101. doi:10.1016/j.ribaf.2016.07.034

McClure, B. (2010). Modern portfolio theory: Why it's still hip. Investopedia. Retrieved on 16/11/2018 from https://www.investopedia.com/articles/06/MPT.asp\#axzz1g3JQY7nY

Mundi, H. S. (2019). Income Streams for Banks and Bank Performance. Journal of Banking and Finance Management, 2(1), 37-42.

Nisar, S., Peng, K., Wang, S., \& Ashraf, B. N. (2018). The impact of revenue diversification on bank profitability and stability: Empirical evidence from South Asian countries. International Journal of Financial Studies, 6(40), 1-25. doi:10.3390/ijfs6020040

Nzotta, S. M., \& Okereke, J. E. (2009). Financial deepening and economic development of Nigeria: An empirical investigation. African Journal of Accounting, Economics. Finance and Banking Research, 5(5), 52-66.

O’Sullivan, A., \& Steven, M. S. (2003). Economics: Principles in action. Pearson Prentice Hall.

Onwudiwe, C. C. (2017). Legal aspects of electronic banking in Nigeria: An overview. A key note paper presented at $C B N$ annual lectures. Managing Partner Harvard Law Firm.

Osundina, C. K., Osundina, J. A., Jayeoba, O. O., \& Olayinka, I. M. (2016). Exchange rate volatility and banks performance: Evidence from Nigeria. International Journal of Economics and Business Management, 2(4), 1-11.

Penrose, E. T. (1959). The theory of the growth of the firm. Wiley.

Ross, S. A., Westerfield, R., \& Jaffe, J. (2002). Capital market theory: An overview. In Corporate Finance (6th ed.). McGraw-Hill.

Sanya, S., \& Wolfe, S. (2011). Can banks in emerging economies benefit from revenue diversification? Journal of Financial Services Research, 40(1), 79-101. doi:10.1007/s10693-010-0098-z

Saunders, A., Schmid, M., \& Walter, I. (2016). Non-interest income and bank performance: Does ring-fencing reduce bank risk? Working Papers on Finance No. 2014/17.

Stiroh, K. J. (2004). Diversification in banking: Is noninterest income the answer? Journal of Money, Credit and Banking, 36(5), 853-882. doi:10.1353/mcb.2004.0076

Stiroh, K. J. (2006). A portfolio view of banking with interest and noninterest activities. Journal of Money, Credit and Banking, 38(5), 135-162. doi:10.1353/mcb.2006.0075

Stiroh, K. J., \& Rumble, A. (2006). The dark side of diversification: The case of US financial holding companies. Journal of Banking \& Finance, 30(8), 2131-2161. doi:10.1016/j.jbankfin.2005.04.030

Tobin, J. (1969). A general equilibrium approach to monetary theory. Journal of Money, Credit and Banking, 1(1), 15-29. doi:10.2307/1991374

Tobin, J. (1978). Monetary policies and the economy: The transmission mechanism. Southern Economic Journal, 37(3), 421-431. doi:10.2307/1057201

Tobin, J., \& Brainard, W. (1968). Pitfalls in financial model building. The American Economic Review, 58, 99-122.

Tobin, J., \& Brainard, W. (1977). Asset markets and the cost of capital. In B. Belassa \& R. Nelson (Eds.), economic progress private values and public policies: Essays in Honor of William Fellner. North-Holland.

Wernerfelt, B., \& Montgomery, C. A. (1988). Tobin's q and the importance of focus in firm performance. The American Economic Review, 78(1), 246-250. 
Williamson, O. E. (1967). Hierarchical control and optimum firm size. Journal of Political Economy, 75(2), 123-138. doi:10.1086/259258

Zeitun, R., \& Tian, G. G. (2007). Capital structure and corporate performance. Evidence from Jordan. Australian Accounting Business and Finance Journal, 1(4), 104-115. doi:10.14453/aabfj.v1i4.3 